\title{
Parasagittal Meningioma
}

National Cancer Institute

\section{Source}

National Cancer Institute. Parasagittal Meningioma. NCI Thesaurus. Code C4960.

A mening ioma that affects the falx cerebri. 